\title{
Juvenile idiopathic arthritis morbidity rate in rural and urban areas of Poland 2008-2012
}

\author{
Małgorzata Tłustochowicz ${ }^{1}$, Andrzej Śliwczyńskii, ${ }^{2,3}$ Petre Iltchev ${ }^{4}$, Melania Brzozowska²,3, \\ Aleksandra Sierocka ${ }^{5}$, Michał Marczak ${ }^{4}$, Witold Tłustochowicz ${ }^{1}$ \\ ${ }^{1}$ Military Institute of Medicine in Warsaw, Poland \\ 2 Public Health Department, Health Sciences Faculty, Medical University in Łódź, Poland \\ ${ }^{3}$ National Health Fund, Warsaw, Poland \\ ${ }^{4}$ Health Care Policy Department, Medical University in Łódź, Poland \\ ${ }^{5} \mathrm{~K}$. Jonscher Hospital in Łódź, Poland
}

Tłustochowicz M, Śliwczyński A, Iltchev P, Brzozowska M, Sierocka A, Marczak M, Tłustochowicz W. Juvenile idiopathic arthritis morbidity rate in rural and urban areas of Poland 2008-2012. Ann Agric Environ Med. 2015; 22(4): 704-707. doi: 10.5604/12321966.1185780

\begin{abstract}
Objective. The aim of this study was to investigate the juvenile idiopathic arthritis (JIA) morbidity rate in the Polish population, calculated per 1,000 inhabitants of a given province, taking into account the differences between urban and rural areas, gender and area of residence (province) 2008-2012.

Method. From the NFZ IT systems information was obtained on the treatment of patients who had M08 and M09 juvenile arthritis, diseases classified elsewhere by the ICD-10 diagnosis code in the settlement report of the hospital. The number of patients, their gender and age at individual diagnoses were calculated based on the PESEL number provided in the statistical reports of the patient with the analysed ICD-10 diagnosis. Urban and rural cases were compared using commune zip codes. The basic for classifying the patient as a member of a urban or rural population was the zip code of the declared place of residence.

Results. In Poland, the number of patients suffering from juvenile idiopathic arthritis has been increasing since 2008 - from 9.2 thousand in 2008 to 11.4 thousand in 2012. The majority were girls (approx. 62\%). Most patients were living in urban areas; in $2008,5.9$ thousand: urban areas $-64 \%$ of women and $36 \%$ of men; 3.2 thousand: rural areas $-62 \%$ of women, $38 \%$ of men); in 2012, 7.2 thousand - urban areas); 4.2 thousand - rural areas. The morbidity indicators ranged from $0.195-0.357$ per 1,000 inhabitants, depending on the year, gender and place of residence (province and commune).
\end{abstract}

\section{Key words}

juvenile idiopathic arthritis, juvenile rheumatoid arthritis, morbidity, urban, rural, province.

\section{INTRODUCTION}

Juvenile Idiopathic Arthritis (JIA) is the most frequent autoimmune disease of the developmental age, with an undetermined etiology. In accordance with the definition, it is an inflammation of joints commencing before the $16^{\text {th }}$ year of age, with a duration of at least 6 weeks, after excluding other causes. It forms a heterogeneous group of diseases with 6 clinical manifestations, with a course of inflammation of one or multiple joints, with a diverse course, clinical presentation and genetic factors. Complications and outcomes in the JIA are frequent and may lead to permanent disability (30\% of observed cases) and death (approx. 10\% of observed cases) $[1,2,3]$. There are no Polish studies concerning the size of the entire population of those afflicted, although it is assumed that in the population of children JIA is diagnosed in 2.6-10/100 thousand children [4]. The lack of registers and more studies on the incidence and morbidity of JIA in Poland prevents any comparisons.

The aim of the current analysis is:

1. to estimate the JIA morbidity indicator for the entire population in Poland;

2. estimation of differences in the morbidity indicator between urban and rural areas and provinces in Poland.

Address for correspondence: Andrzej Śliwczyński, Department of Analyses and Strategy National Health Fund, Grójecka 186, 02-390 Warsaw, Poland

E-mail: andrzej.sliwczynski@nfz.gov.pl

Received: 08 October 2013; accepted: 27 December 2013

\section{MATERIALS AND METHOD}

Health services in Poland are financed by the National Health Service (NFZ), pursuant to the Act [5] and the Regulation of the Minister of Health resulting thereof [6]. The rules of organisation, financing and settling of the services are set out for the service providers in the Regulations of the President of the NFZ [7]. When creating a database concerning arthritic diseases, the NFZ IT systems were used to provide information on the treatment of all patients who had M08 Juvenile arthritis and M09 Juvenile arthritis in diseases classified elsewhere as the ICD-10 code as the main diagnosis in the settlement report. Data for all types of services were used for analysis, and no age restriction was introduced (the studied population was not filtered by age). Patients undergoing therapy for other disease were also taken into account, with M08.X or M09.X as a coexisting diagnosis. The number of patients and their gender for individual diagnoses were calculated based on the PESEL number provided in the statistical reports of the patient with the analysed ICD-10 diagnosis.

The data was collected from the databases using SQL tools, using a filter in accordance with the accepted scope of ICD10 diagnoses (M08.X or M09.X), the analysis was conducted using Excel and Statistica 10 tools. Demographic data was collected from the Central Statistical Office website [8]. Analysis presented the lack of data on two levels: incorrectly provided (non-existing) PESEL Number or incorrectly 
provided or not provided domicile address. (This situation occurs when the therapy is provided, e.g. for a homeless person). The number of incorrect data did not exceed $0.2 \%$ and had no impact on statistical significance (in 2008 it amounted to $0.15 \% ; 2009-0.13 \% ; 2010-0.14 \% ; 2011-$ $0.12 \% ; 2012-0.12 \%)$. Division into the type of commune was performed using the territory identifier, based on the postal code of the patient's place of residence. In accordance with the accepted definition, morbidity [9] was assumed to be an indicator stating how many persons were suffering from the given disease at a given moment, i.e. the number of all persons who had the JIA diagnosis as the main or co-existing diagnosis in a given year.

\section{RESULTS}

The number of patients indicated in Poland in individual years varied from 9,273 in 2008 - 11,498 in 2012 (Tab. 1). The number of patients resulting from totalling the numbers in individual provinces is higher than the number for the whole of Poland by approximately $5 \%$, which probably results from the movement of patients between treatment centres in various provinces (so-called migration indicator). The least number of patients were recorded in Lubuskie and Podlaskie provinces, the most in Mazowieckie and Śląskie provinces.

In the case of analysis based only on the main diagnoses the number of patients was reduced by approx. $22 \%$. Most patients were living in urban areas - since 2008, 5.9 thousand patients lived in urban areas (64\% of girls and $36 \%$ of boys) and only 3.2 thousand patients in rural areas (62\% of girls and $38 \%$ of boys), and in 2012, 7.2 thousand and 4.2 thousand, respectively.

Table 1. Number of patients in individual provinces during the years 2008-2012

\begin{tabular}{lrrrrr}
\hline \multicolumn{1}{c}{ Province } & \multicolumn{1}{c}{2008} & 2009 & 2010 & 2011 & 2012 \\
\hline DOLNOŚLASKI & 576 & 555 & 623 & 1015 & 1061 \\
\hline KUJAWSKO-POMORSKI & 487 & 490 & 522 & 563 & 530 \\
\hline LUBELSKI & 645 & 674 & 669 & 660 & 622 \\
\hline LUBUSKI & 117 & 111 & 117 & 190 & 223 \\
\hline ŁÓDZKI & 504 & 701 & 654 & 701 & 743 \\
\hline MAŁOPOLSKI & 776 & 812 & 909 & 1084 & 1167 \\
\hline MAZOWIECKI & 1501 & 1969 & 1967 & 2110 & 2117 \\
\hline OPOLSKI & 201 & 178 & 187 & 215 & 205 \\
\hline PODKARPACKI & 531 & 561 & 506 & 700 & 756 \\
\hline PODLASKI & 246 & 273 & 301 & 280 & 284 \\
\hline POMORSKI & 505 & 475 & 559 & 700 & 732 \\
\hline ŚLASKI & 1269 & 1182 & 1229 & 1540 & 1550 \\
\hline ŚWIĘTOKRZYSKI & 503 & 506 & 442 & 395 & 394 \\
\hline WARMIŃSKO-MAZURSKI & 319 & 302 & 276 & 316 & 294 \\
\hline WIELKOPOLSKI & 887 & 1042 & 939 & 833 & 874 \\
\hline ZACHODNIOPOMORSKI & 500 & 920 & 558 & 576 & 627 \\
\hline Polish provinces, total & $\mathbf{9 5 6 7}$ & $\mathbf{1 0 7 5 1}$ & $\mathbf{1 0 4 5 8}$ & $\mathbf{1 1 8 7 8}$ & $\mathbf{1 2} \mathbf{1 7 9}$ \\
\hline Poland, total & $\mathbf{9 2 7 3}$ & $\mathbf{1 0} \mathbf{1 8 0}$ & $\mathbf{9 8 1 4}$ & $\mathbf{1 1 1 6 5}$ & $\mathbf{1 1 4 9 8}$ \\
\hline Urban areas - women & $\mathbf{3 7 8 7}$ & $\mathbf{4 3 1 1}$ & 4022 & 4671 & 4813 \\
\hline Urban areas - men & $\mathbf{2 3 6 2}$ & 2546 & 2545 & 2796 & 2856 \\
\hline Rural areas - women & 2362 & 2338 & 2683 & 2729 \\
\hline Rural areas - men & 1509 & 1531 & 1705 & 1746 \\
\hline
\end{tabular}

The highest morbidity indicator was observed in 2012 (value of 0.298 per 1,000 inhabitants), the lowest indicator occurred in 2008 (value of 0.243 per 1,000 inhabitants) (Tab. 2). In all the years, morbidity among girls was higher than among boys. The ratio of the number of girls to the number of boys amounted in the studied period to an average of 1.6:1, and did not fall below 1.5:1.

Table 2. JIA morbidity indicator for the Polish population, divided by sex

\begin{tabular}{llllll}
\hline & 2008 & 2009 & 2010 & 2011 & 2012 \\
\hline Women & 0.288 & 0.320 & 0.301 & 0.347 & 0.357 \\
\hline Men & 0.195 & 0.210 & 0.210 & 0.228 & 0.236 \\
\hline Poland & $\mathbf{0 . 2 4 3}$ & $\mathbf{0 . 2 6 7}$ & $\mathbf{0 . 2 5 7}$ & $\mathbf{0 . 2 9 0}$ & $\mathbf{0 . 2 9 8}$ \\
\hline
\end{tabular}

Indicators were higher in urban communes than in rural communes (Tab. 3), this disproportion existed for both genders (Tab. 4). In urban communes, on average, $9 \%$ more girls were ill and approx. $14 \%$ of boys. The highest indicator for the population of both urban and rural communes in the studied period was established in 2012, and only applied to girls (values of, respectively, 0.369 and 0.336 persons per 1,000 inhabitants). The lowest indicator was observed for rural communes in 2008, for boys (0.175).

Table 3. JIA morbidity indicators per 1 thousand inhabitants, depending on the commune

\begin{tabular}{llllll}
\hline & 2008 & 2009 & 2010 & 2011 & 2012 \\
\hline Urban communes & 0.264 & 0.295 & 0.282 & 0.319 & 0.328 \\
\hline Rural communes & 0.229 & 0.260 & 0.260 & 0.290 & 0.295
\end{tabular}

Table 4. JIA morbidity indicator in the years 2008-2012 per 1 thousand inhabitants, divided by the place of residence, taking into account sex

\begin{tabular}{|c|c|c|c|c|c|}
\hline & 2008 & 2009 & 2010 & 2011 & 2012 \\
\hline \multicolumn{6}{|c|}{ Sex } \\
\hline Urban communes & 0.300 & 0.333 & 0.308 & 0.357 & 0.369 \\
\hline Rural communes & 0.268 & 0.298 & 0.290 & 0.332 & 0.336 \\
\hline \multicolumn{6}{|c|}{ Boy } \\
\hline Urban communes & 0.208 & 0.221 & 0.219 & 0.238 & 0.246 \\
\hline Rural communes & 0.175 & 0.193 & 0.194 & 0.212 & 0.220 \\
\hline Poland & 0.243 & 0.267 & 0.257 & 0.290 & 0.298 \\
\hline
\end{tabular}

The lowest value of the indicator for urban areas was found in Lubuskie province (average value for 2008-2012 amounted to 0.156 patients per 1,000 inhabitants); the highest value was found in Zachodniopomorskie province (average value of the indicator 0.396 per 1,000 inhabitants) (Tab. 5). The following provinces also had a high average value of the morbidity indicator for urban areas: Świętokrzyskie (0.384); Mazowieckie (0.376) and Lubelskie (0.371). Low values for urban areas also occurred in the following provinces: Opolskie (0.182) and Warmińsko-Mazurskie (0.214). For rural areas, the lowest average indicator value for the studied period was observed in the provinces: Lubuskie (0.136); Podlaskie (0.187); Warmińsko-Mazurskie (0.203). The highest values were present in the provinces: Mazowieckie (0.351); Świętokrzyskie (0.325) and Zachodniopomorskie (0.321).

Figure 1 represents in a graphic form the changes of this indicator in the period of 2008-2012, for regions where the 
Table 5. JIA morbidity indicator in the years 2008-2012 in Poland per 1000 inhabitants, divided by the region, taking into account provinces

\begin{tabular}{|c|c|c|c|c|c|}
\hline & 2008 & 2009 & 2010 & 2011 & 2012 \\
\hline Urban communes & 0.264 & 0.295 & 0.282 & 0.319 & 0.328 \\
\hline DOLNOŚLĄSKIE & 0.208 & 0.216 & 0.216 & 0.353 & 0.368 \\
\hline KUJAWSKO-POMORSKIE & 0.334 & 0.348 & 0.348 & 0.277 & 0.260 \\
\hline LUBELSKIE & 0.418 & 0.435 & 0.347 & 0.321 & 0.334 \\
\hline LUBUSKIE & 0.132 & 0.115 & 0.126 & 0.188 & 0.219 \\
\hline ŁÓDZKIE & 0.208 & 0.292 & 0.275 & 0.291 & 0.313 \\
\hline MAŁOPOLSKIE & 0.233 & 0.240 & 0.268 & 0.339 & 0.348 \\
\hline MAZOWIECKIE & 0.299 & 0.387 & 0.375 & 0.406 & 0.414 \\
\hline OPOLSKIE & 0.194 & 0.145 & 0.171 & 0.209 & 0.190 \\
\hline PODKARPACKIE & 0.254 & 0.264 & 0.235 & 0.308 & 0.364 \\
\hline PODLASKIE & 0.235 & 0.268 & 0.274 & 0.262 & 0.262 \\
\hline POMORSKIE & 0.250 & 0.223 & 0.263 & 0.312 & 0.322 \\
\hline ŚLĄSKIE & 0.291 & 0.275 & 0.280 & 0.342 & 0.336 \\
\hline ŚWIĘTOKRZYSKIE & 0.477 & 0.448 & 0.358 & 0.327 & 0.311 \\
\hline WARMIŃSKO-MAZURSKIE & 0.220 & 0.222 & 0.200 & 0.218 & 0.209 \\
\hline WIELKOPOLSKIE & 0.274 & 0.316 & 0.282 & 0.247 & 0.278 \\
\hline ZACHODNIOPOMORSKIE & 0.324 & 0.581 & 0.347 & 0.358 & 0.368 \\
\hline Rural communes & 0.229 & 0.260 & 0.260 & 0.290 & 0.295 \\
\hline DOLNOŚLĄSKIE & 0.178 & 0.167 & 0.213 & 0.337 & 0.352 \\
\hline KUJAWSKO-POMORSKIE & 0.228 & 0.218 & 0.231 & 0.254 & 0.241 \\
\hline LUBELSKIE & 0.266 & 0.289 & 0.277 & 0.288 & 0.244 \\
\hline LUBUSKIE & 0.087 & 0.098 & 0.098 & 0.182 & 0.214 \\
\hline ŁÓDZKIE & 0.176 & 0.245 & 0.224 & 0.246 & 0.254 \\
\hline MAŁOPOLSKIE & 0.239 & 0.251 & 0.282 & 0.309 & 0.348 \\
\hline MAZOWIECKIE & 0.266 & 0.357 & 0.376 & 0.384 & 0.374 \\
\hline OPOLSKIE & 0.193 & 0.203 & 0.189 & 0.215 & 0.213 \\
\hline PODKARPACKIE & 0.252 & 0.268 & 0.243 & 0.344 & 0.347 \\
\hline PODLASKIE & 0.164 & 0.169 & 0.219 & 0.189 & 0.197 \\
\hline POMORSKIE & 0.183 & 0.194 & 0.223 & 0.292 & 0.313 \\
\hline ŚLĄSKIE & 0.210 & 0.181 & 0.210 & 0.298 & 0.329 \\
\hline ŚWIĘTOKRZYSKIE & 0.327 & 0.356 & 0.340 & 0.295 & 0.305 \\
\hline WARMIŃSKO-MAZURSKIE & 0.229 & 0.196 & 0.183 & 0.215 & 0.193 \\
\hline WIELKOPOLSKIE & 0.243 & 0.292 & 0.265 & 0.232 & 0.219 \\
\hline ZACHODNIOPOMORSKIE & 0.233 & 0.456 & 0.286 & 0.278 & 0.350 \\
\hline
\end{tabular}

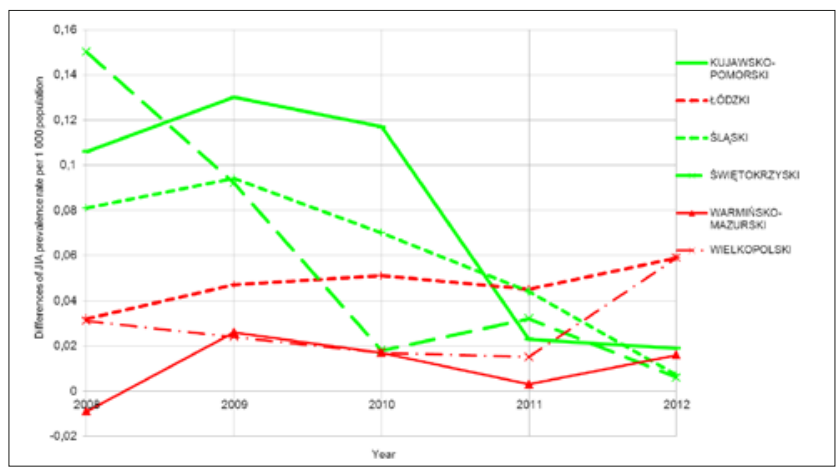

Figure 1. Biggest differences in prevalence rate per 1,000 population of JIA between urban and rural residents 2008-2012

differences between urban and rural areas have grown most rapidly, and for regions where there was the largest advance in decreasing the difference.
As can be seen, large differences were observed in 20092010 in the Świętokrzyskie, Kujawsko-Pomorskie and Śląskie provinces, but decreased in subsequent years.

\section{DISCUSSION}

The number of patients suffering from Juvenile Idiopatic Arthritis in Poland during the analysed period has increased since the year 2008, which was treated as the initial year in the current study. There were approx. 9.3 thousand then, and in 2012 this number had increased to 11.5 thousand. Approximately 5\% of patients were treated in more than one province. Since, to the Authors' best knowledge, this is the first population study for the whole of Poland, it is not possible to refer to other publications. $22 \%$ of patients during this period were probably most actively treated for JIA, or were treated only by family doctors, who do not provide diagnostic codes; their visits were filed by doctors other than rheumatologists. As indicated by the observations by many authors [10], a significant percentage of JIA patients still have the disease after reaching adulthood, but many of them experience remission. However, they also require treatment by specialists other than rheumatologists, due to their short stature, physical disability, osteoporosis, dysfunctions of internal organs and of sight, and sometimes amyloidosis [11]. Since the assumption of the current study was to include all patients with diagnosed JIA, no filter restricting the population to 16 years of age was applied, which was the limit of the illness diagnosis, in accordance with the recommendations the diagnosis once made remains in force until the patient's death [12]. The highest morbidity indicator was observed in 2012 and reached the value of 0.298 per 1,000 inhabitants, a value which should be assumed to be current, but there are no other Polish data for comparison. The only available data concern the morbidity indicators, which for the Łódzkie and Kieleckie provinces amounted to 5 and 6.5, respectively, per 100,000 children [4].

Most patients lived in urban areas - in 2008, 5.9 thousands and in 2012 in rural areas, respectively, 3.2 thousand and 4.2 thousand. Morbidity indicators were also higher in urban communes than in rural communes, and there was a large disproportion between provinces which changed during the studied period. The lowest value of the indicator for both urban and rural areas was present in Lubuskie province (average value for 2008-2012 amounted to 0.156 patients per 1,000 inhabitants, 0.219 in 2012 for urban areas and 0.214 for rural areas); the highest value was present in Zachodniopomorskie province (respectively, 0.396, 0.368 and 350 ). The following provinces also had a high average value of the morbidity indicator for urban areas in 2008-2012: Świętokrzyskie, Mazowieckie and Lubelskie province. Low values also occurred for urban areas in the Opolskie and Warmińsko-Mazurskie provinces. For rural areas, the low average value of the indicator from the studied period was also observed in Podlaskie and WarmińskoMazurskie provinces, whereas high values in Mazowieckie and Świętokrzyskie provinces. Currently, it is difficult to interpret these results in a manner other than the availability of hospitals and rheumatologists to patients. Which is how the high differences between indicators in rural and urban areas in Śląskie and Świętokrzyskie provinces in 2008 and their decrease in 2012 should be interpreted. 
In all the years, morbidity among girls was higher than among boys, they amounted to $62-64 \%$ of the patients. The ratio of the number of girls to the number of boys amounted in the studied period to an average of 1.6:1, and did not fall below 1.5:1. Similar relationships were observed in quoted studies concerning Łódzkie and Świętokrzyskie provinces. In urban communes, an average of $9 \%$ more girls were ill and approx. $14 \%$ of boys.

International data concerning morbidity are very divergent, the publications have presented a gradient of morbidity between the North and South of Europe [15]. In Norway, morbidity per 100,000 inhabitants amounted to 14 in 2008, in Spain to 7 in 2010, in Estonia to 22 in 2007, and in the Czech Republic to 13 in 2006 [17, 18], in France - 19.8, whereas in US and in Sweden - 86.1, and in Australia - 440, much more than in Poland $[4,13]$. Data from other countries indicate that the illness is present more frequently among girls than among boys (in proportion of 1.5-2:1), thus, similar to Poland. In European countries and in the USA, the more frequent presence of the oligoarthritic form (approx. 60\% of cases), and in Asian and African countries, poliarthritic and the generalised form is present [14]. In the presented study, no differentiation was made between the individual forms of the disease.

There are no published data concerning morbidity divided by urban and rural areas in Europe. The only available data concern solely the value of the morbidity indicator per 100,000 inhabitants, calculated based on medical registers or population studies. The number of patients per 100,000 inhabitants in Spain amounted to 40, which was similar to Poland, whereas in Estonia it amounted to 84, and in the Czech Republic to 140. Pruunsild et al. stipulate for Estonia in 1998-2000 the indicator with a value of 21.7 - 19.3 for boys, and 22.9 for girls [15]. Studies from Scandinavian countries state that this indicator amounted to 15 per 100,000 [16]. According to Nielsen et al. [17], children living in cities are at higher risk of JIA. Radon et al. have inferred that neither the place of residence (urban vs. rural), nor regular contact with farm animals or with pets during infancy are factors related to JIA morbidity [18]. The analysis conducted in the study indicated that the frequency of diagnosis depends more on the province than the commune of residence. Morbidity is lower in then provinces, where there are less rheumatologists, in approximately $10 \%$ of districts in Poland there is no rheumatology clinic [19]. There is no data concerning the number of children's rheumatologists employed in Poland, their number is estimated to be approximately 70-80, with the total number of rheumatologists being 1,500 (a similar situation is present in the UK where there are only 26 children's rheumatologists [20]).

\section{REFERENCES}

1. Ravelli A, Martini A. Juvenile idiopathic arthritis. Lancet 2007; 369: 767-778.

2. Romicka A. Młodzieńcze idiopatyczne zapalenie stawów - obraz kliniczny, przebieg i leczenie. Standardy medyczne. (Juvenile idiopathic arthritis - clinical picture, course and treatment. Medical standards.) Pediatria, 2010; 7(2): 189-193 (in Polish).

3. Petty RE, Southwood TR, Manners P, et al. International League of Associations for Rheumatology classification of juvenile idiopathic arthritis: second revision, Edmonton, 2001. J Rheumatol. 2004; 31: 390-2.

4. Rutkowska-Sak L, Gietka P, Wierzbowska M, et al. Reumatologia wieku rozwojowego. Zalecenia konsultanta krajowego w dziedzinie reumatologii dotyczące diagnostyki i leczenia chorób reumatycznych. (Rheumatology of developmental age. Recommendations of the national rheumatology consultant on the diagnostics and treatment of rheumatological diseases). Reumatologia 2012; 50(2): 142-161 (in Polish).

5. Ustawa z dnia 27.08.2004 r. o świadczeniach opieki zdrowotnej finansowanych ze środków publicznych (Dz. U. z 2008 r. Nr 164, poz. 1027, z późn. zm.). 27 August 2004 Act on health care services financed from public means (Dz. U. of 2008, no. 164, item 1027 as amended).

6. http://www.mz.gov.pl/wwwmz/index?mr\&ms\&ml=pl\&mi=92\&mx= $0 \& \mathrm{ma}=10772$ (access: 2013.08.31).

7. http://www.nfz.gov.pl/new/index.php?katnr=3\&dzialnr=12 (access: 2013.07.30).

8. http://www.stat.gov.pl (access: 2013.06.30).

9. Porta M. A Dictionary of Epidemiology, Oxford University Press, Oxford, 2008.

10. Camuglia JE, Whitford CL, Hall AJ. Juvenile idiopathic arthritis associated uveitis in adults: a case series. Ocul Immunol Inflamm. 2009 Sep-Oct;17(5): 330-4.

11. Skarin A, Elborgh R, Edlund E, et al. Long-term follow-up of patients with uveitis associated with juvenile idiopathic arthritis: a cohort study. Ocul Immunol Inflamm. 2009 Mar-Apr;17(2):104-8.

12. L. Rutkowska-Sak, M. Majdan, M. Tłustochowicz, W. Tłustochowicz: Przewlekłe zapalenia stawów - przejście od reumatologa pediatry do reumatologa dorosłych. Zalecenia Zespołu Ekspertów przy Konsultancie Krajowym w dziedzinie reumatologii w kontekście uwarunkowań związanych z przestrzeganiem zapisów programów terapeutycznych. (Arthritis - from a paediatric rheumatologist to an adult rheumatologists. Recommendations of the National Consultant's Team of Experts on rheumatology within the framework of therapeutic programmes). Reumatologia 2013; 51(4): 259-264 (in Polish).

13. Puszczewicz M. Wielka interna - reumatologia. wyd. I (Internal medicine compendium - rheumatology, $1^{\text {st }}$ ed.), Medical Tribune Polska, Warszawa, 2000 (in Polish).

14. Petty RE, Smith JR, Rosenbaum JT. Arthritis and uveitis in children:a pediatric rheumatology perspective. Am J Ophthamol. 2003;135(6): 879-84.

15. Pruunsild C, Uibo K, Liivamagi H, Tarraste S, Talvik T, Pelkonen P. Incidence of juvenile idiopathic arthritis in children in Estonia: a prospective population-based study. Scand J Rheumatol. 2007; 36: 7-13. http://www.clinexprheumatol.org/article.asp? $\mathrm{a}=3134$

16. Berntson L, Andersson GB, Fasth A, Herlin T, Kristinsson J, Lahdenne P, Marhaug G, Nielsen S, Pelkonen P, Rygg M, Nordic Study Group: Incidence of juvenile idiopathic arthritis in the Nordic countries. A population based study with special reference to the validity of the ILAR and EULAR criteria. J Rheumatol. 2003; 30: 2275-2282.

17. Nielsen HE, Dorup J, Herlin T, Larsen K, Nielsen S, Pedersen FK. Epidemiology of juvenile chronic arthritis: risk dependent on sibship, parental income, and housing. J Rheumatol. 1999; 26(7): 1600-1605.

18. Radon K, Windstetter D, Poluda D, Häfner R, Thomas S, Michels $\mathrm{H}$, von Mutius E. Exposure to animals and risk of oligoarticular juvenile idiopathic arthritis: a multicenter case-control study. BMC Musculoskelet Disord. 2010 Apr 20; 11: 73.

19. Drapała A, Grabowska Woźniak E, Gryglewicz J, et al. Stan opieki reumatologicznej w Polsce. Streszczenie raportu projektu badawczego. (Condition of rheumatological care in Poland. Abstract of a study project report). Uczelnia Łazarskiego, Warszawa 2011 (in Polish).

20. Wilkinson N.Children Don't Get Arthritis, Do They? Executive Member of British Society for Paediatric and Adolescent Rheumatology (BSPAR). Autumn 2012. http://www.nras.org.uk/about_rheumatoid_arthritis/ what_is_ra/what_is_jia_aosd/what_is_jia/information_on_jia/ children_dont_get_arthritis_do_they.aspx (Accessed on 19.07.2013). 